\title{
Insulin-like growth factor (IGF)-I, IGF-II, IGF-binding protein-2 and pregnancy-associated glycoprotein mRNA in pigs with somatotropin-enhanced fetal growth
}

\author{
J A Sterle, C K Boyd, J T Peacock, A T Koenigsfeld, \\ W R Lamberson, D E Gerrard ${ }^{1}$ and M C Lucy \\ Department of Animal Sciences, 164 ASRC, University of Missouri, Columbia, Missouri 65211, USA and ${ }^{1}$ Department of Animal Sciences, B1 Smith Hall, \\ Purdue University, West Lafayette, Indiana 47907, USA \\ (Requests for offprints should be addressed to M C Lucy)
}

\begin{abstract}
Fetal growth is increased when pregnant gilts are treated with recombinant porcine somatotropin. The mechanism for increased fetal growth was examined by measuring the expression of IGF-I and -II and IGF-binding protein-2 (IGFBP-2) mRNA in liver and reproductive tissues of somatotropin- and saline-treated pregnant gilts.

Twenty-four pregnant gilts received daily injections of either saline (control; $n=12$ ) or $5 \mathrm{mg}$ recombinant porcine somatotropin $(n=12)$ from day 30 to day 43 of gestation. Gilts were slaughtered on day 44 of gestation and liver, ovary, placenta, placental uterus (uterus with adjacent placental tissue) and non-placental uterus (region of the necrotic tip) were collected. The mRNAs for somatotropin receptor, IGFs -I and -II, IGFBP-2 and pregnancyassociated glycoprotein (a marker of trophoblast tissue) were analyzed by Northern blotting or ribonuclease protection assay.

Gilts treated with somatotropin had heavier fetuses and placentas. The concentration of mRNA for the

components of the IGF system was tissue-dependent. The uterine IGF-I mRNA concentration was greater in nonplacental than in placental uterus. The greatest IGF-II mRNA concentration was observed in placenta, and adjacent uterine tissue expressed IGFBP-2 mRNA intensely. In non-placental uterus, IGFBP-2 mRNA was nearly undetectable. Somatotropin-dependent regulation of IGF-I was only observed in liver, where the greatest somatotropin receptor mRNA concentration was found. In the pregnant uterus, somatotropin failed to change the concentration of IGF or IGFBP-2 mRNA. Pregnancyassociated glycoprotein mRNA concentration was decreased by somatotropin.

In summary, increased fetal growth in somatotropintreated pregnant pigs was not associated with changes in IGF or IGFBP-2 mRNA concentration in reproductive tissues. Other mechanisms, therefore, lead to enhanced fetal growth in somatotropin-treated pregnant pigs.

Journal of Endocrinology (1998) 159, 441-450
\end{abstract}

\section{Introduction}

Fetal growth is a complex process that depends on the transfer of maternal nutrients across the placenta, and the expression of fetal and placental growth factors and morphogens that control development (D'Ercole \& Underwood 1981, Han \& Hill 1992). The rate of fetal growth is partially dependent on the insulin-like growth factor (IGF) system that co-ordinates several aspects of uterine, placental, and fetal development (Owens 1991). The IGF system consists of two related growth factors (IGF-I and -II) and a group of IGF-binding proteins (IGFBPs; Jones \& Clemmons 1995). The IGFBPs can modify IGF activity by binding IGFs and preventing IGF receptor activation. It is also possible that IGFBPs have actions that are independent of their roles as proteins that bind IGFs (Rechler 1997).
Uterine tissues express components of the IGF system in a tissue- and developmentally specific pattern. In the pig, most IGF-I mRNA is found within the myometrium (Song et al. 1996), but endometrial IGF-I is steroidogenically regulated during early pregnancy (Simmen et al. 1990). The placenta is the primary location of fetal IGF-II production. Later in porcine pregnancy, endometrial IGF-I decreases (Simmen et al. 1992), but uterine IGFBP-2 (the predominant IGFBP in porcine uterus during pregnancy) increases within the endometrium (Song et al. 1996). The importance of IGF-I and IGF-II for fetal development was demonstrated in gene knockout experiments in which mice with deletion of either gene were born at 60\% of normal weight (Baker et al. 1993). The conclusion was that both IGF-I and IGF-II are required for fetal growth. 
In addition to the locally acting IGFs (either uterine IGF-I or placental IGF-II), maternal blood IGF-I concentrations appear to play a role in fetal development. In humans, farm animals, and laboratory animals, maternal IGF-I concentrations are correlated with the size of the fetus and birth weight (Hall et al. 1986, Gluckman \& Barry 1988, Lassarre et al. 1991, Gluckman et al. 1992). It may be possible, therefore, to increase fetal development and birth weight by increasing maternal IGF-I concentrations during pregnancy. Indeed, fetal or neonatal weight was increased when recombinant porcine somatotropin (rpST) was administered and maternal IGF-I increased during pregnancy (Rehfeldt et al. 1993, Kelley et al. 1995, Sterle et al. 1995). An important observation from these studies was that porcine fetuses with the least uterine space demonstrated the greatest growth in response to rpST (Sterle et al. 1995). These results suggested that rpST and/or IGF-I can act as a uterine or fetal growth factor. Alternatively, metabolic or endocrine changes that occur after somatotropin treatment (i.e. increased glucose, insulin and free fatty acids; Gopinath \& Etherton 1989, Dunshea et al. 1992, Buonomo et al. 1995, Hansen et al. 1997) may increase the nutrients available in pregnancy. In either case, gestational administration of $\mathrm{rpST}$ may be a method to increase birth weight and improve neonatal survival.

The molecular mechanisms leading to increased fetal growth in response to somatotropin are undefined. Any direct effects of rpST on the pregnant uterus should depend on somatotropin receptor location. The objectives of this study were, therefore, to determine the tissue location of somatotropin receptor in the pregnant pig and to assay liver (the traditional site for somatotropin action) as well as reproductive tissues for changes in IGF-I, IGF-II, and IGFBP-2 gene expression in response to rpST during pregnancy. Pregnancy-associated glycoprotein (PAG) was also measured as a marker of placental development.

\section{Materials and Methods}

\section{Animals, treatments and collection of tissues}

Twenty-four crossbred (Yorkshire $\times$ Landrace) gilts (Sus scrofa, domestica) were used. Gilts were artificially inseminated at their second post-pubertal estrus (6-8 months of age). Approximately 21 days following insemination, gilts were checked with a boar for return to estrus, and blood was analyzed for progesterone concentration. Gilts that failed to express estrus and had elevated progesterone $(>10 \mathrm{ng} / \mathrm{ml})$ were classified as pregnant.

Pregnant gilts were assigned to the experiment. The experiment contained three replicates. Replicates 1 and 2 consisted of 6 gilts each (12 gilts total; $6 \mathrm{rpST}$ and 6 control). Replicate 3 consisted of 12 gilts ( $6 \mathrm{rpST}$ and 6 control). Gilts in replicate 3 had one uterine horn ligated to give a 2:1 ratio of uterine space per potential conceptus between the crowded and uncrowded pregnant horns (Dziuk 1968, Sterle et al. 1995). The uterine crowding was done to satisfy the objectives of a related experiment (Sterle et al. 1995) and did not compromise the objective of the present experiment, because treatment (rpST or saline) was balanced within the replicate.

Gilts were randomly assigned within each replicate to receive daily intramuscular injections of $1 \mathrm{ml}$ saline (control) or $5 \mathrm{mg}$ rpST (Monsanto, St Louis, MO, USA) in $1 \mathrm{ml}$ injectable water from day 30 to day 43 of gestation. Gilts were grouped until day 44 of gestation, when they were slaughtered by electrocution and exsanguination according to University of Missouri Animal Care and Use Committee guidelines.

The uterus was recovered within 5 min of exsanguination and individual fetuses were weighed. Immediately after removal of the fetuses, samples of ovary (corpora lutea (CL) and follicles isolated and frozen separately or frozen together as whole ovary), uterus, placenta and liver were placed in separate plastic vials and frozen in liquid nitrogen. Uterine tissues were collected from two locations. The first location was the uterus adjacent to the placenta (placental uterus). The placenta was stripped from the uterus, weighed, and uterine and placental tissue sampled and frozen separately. The placenta and placental uterus were collected from the second fetus of a uterine horn (the first fetus was adjacent to the tip of uterus). A second uterine sample was taken from the region between the second and third placenta, in the region of the necrotic tips. This was termed non-placental uterus. Uterine samples were collected from the crowded uterine horn in replicate 3. In four gilts (two $\mathrm{rpST}$ and two control), endometrium and myometrium were isolated from a second placental location. After freezing in liquid nitrogen, all samples were stored at $-80{ }^{\circ} \mathrm{C}$ until RNA extraction.

\section{Isolation of RNA}

Unless otherwise noted, chemicals and reagents were purchased from the Sigma Chemical Company (St Louis, MO, USA). Frozen tissue was removed from storage at $-80^{\circ} \mathrm{C}$ and mortared to a fine powder under liquid nitrogen. The powder was then homogenized in $4 \mathrm{M}$ guanidinium thiocyanate, and RNA isolated according to Chomczynski \& Sacchi (1987). Integrity of rRNA was monitored by electrophoresis of an aliquot of the RNA preparation through $1 \%$ agarose in Tris-borate/EDTA (0.09 M Tris-borate, 0.002 M EDTA) with $1.25 \mu \mathrm{M}$ ethidium bromide, followed by ultraviolet illumination. Purified RNA was dissolved in $\mathrm{H}_{2} \mathrm{O}$, quantified based on $\mathrm{A}_{260}$ measurement, and stored at $-80^{\circ} \mathrm{C}$.

\section{Northern blotting}

Five of six gilts from replicates 1 and 2 were randomly selected from each treatment for analyses of somatotropin 
receptor, IGF-II, IGFBP-2 and PAG mRNA and 28S rRNA (control) by Northern blotting. Analysis of RNA by Northern blotting was performed as previously described (Lucy et al. 1993). Total cellular RNA (25 $\mu \mathrm{g})$ was electrophoresed after denaturation with $1 \mathrm{M}$ glyoxal and $50 \%$ dimethyl sulfoxide in a $1 \cdot 2 \%$ agarose gel in $10 \mathrm{mM}$ sodium phosphate ( $\mathrm{pH}$ 6.5). A reduced amount of RNA $(2 \cdot 5 \mu \mathrm{g})$ was used for IGF-II and PAG blots for placenta samples. The RNA was transferred to nitrocellulose by capillary transfer for $15 \mathrm{~h}$ in 20-strength SSPE ( $3 \mathrm{M} \mathrm{NaCl}, 0 \cdot 2 \mathrm{M} \mathrm{NaH}_{2} \mathrm{PO}_{4}, 0 \cdot 2 \mathrm{M}$ EDTA, $\mathrm{pH} 7 \cdot 0$ ) and the nitrocellulose was prehybridized for $2 \mathrm{~h}$ at $42{ }^{\circ} \mathrm{C}$ in $50 \% \quad(\mathrm{v} / \mathrm{v})$ formamide, 5-strength SSPE, 5-strength Denhardt's solution, $0 \cdot 1 \%(\mathrm{w} / \mathrm{v})$ SDS and $100 \mu \mathrm{g} / \mathrm{ml}$ tRNA. Following prehybridization, the filter was incubated in the prehybridization solution for $24 \mathrm{~h}$ at $42{ }^{\circ} \mathrm{C}$ with a ${ }^{32} \mathrm{P}-$ labelled cDNA probe.

The cDNA probes were bovine somatotropin receptor (Hauser et al. 1990), porcine IGF-II (Yuan et al. 1996a), bovine IGFBP-2 (Kirby et al. 1996), porcine PAG (a mixture of porcine PAG1 and PAG2; Szafranska et al. 1995) and porcine 28S rRNA (Yuan et al. 1996b). Labeling of the cDNA probes was by random priming (Multiprime DNA Labeling Systems, Amersham International, Amersham, Bucks, UK) using $[\alpha-$ $\left.{ }^{32} \mathrm{P}\right] \mathrm{dCTP}$.

Northern blot washing conditions were: $2 \times 15 \mathrm{~min}$ : 1-strength SSC $(0 \cdot 15 \mathrm{M} \mathrm{NaCl}, 0 \cdot 017 \mathrm{M}$ sodium citrate, $\mathrm{pH} 7 \cdot 0), 0 \cdot 1 \% \operatorname{SDS}, 50{ }^{\circ} \mathrm{C}$; followed by $10 \mathrm{~min}: 0 \cdot 1-$ strength SSC, $0 \cdot 1 \%$ SDS, $50{ }^{\circ} \mathrm{C}$. Autoradiography was performed using XOMAT-AR film (Eastman Kodak, Rochester, NY, USA) for $12-72 \mathrm{~h}$ at $-80{ }^{\circ} \mathrm{C}$ with an intensifying screen. As a positive control for RNA loading and transfer, blots were stripped of labeled probe by incubating in boiling $\mathrm{H}_{2} \mathrm{O}$ for $30 \mathrm{~min}$ and hybridized with a $28 \mathrm{~S}$ rRNA probe using the conditions described above. Some blots were stripped and hybridized several times with several different cDNA probes.

\section{Analysis of RNA by ribonuclease protection assay}

The porcine IGF-I ribonuclease protection assay was used for analyses in replicates 1,2 and 3. Additional gilts in replicate 3 were used because IGF-I mRNA showed greater between-animal variability than the other mRNA. Therefore, to increase the sensitivity of the statistical analyses, replicate 3 gilts were randomly selected from each treatment and analyzed for IGF-I mRNA. The porcine IGF-I cDNA fragment used for production of the complementary ribonucleotide probe has been described previously (Yuan et al. 1996a). Antisense ribonucleotide probes were generated by using a Riboprobe Gemini II Core system (Promega Corporation, Madison, WI, USA). Linearized plasmid (200 ng) was incubated with T7 polymerase (Promega), $\left[\alpha-{ }^{32} \mathrm{P}\right] \mathrm{rCTP}$ (New England Nuclear, Boston, MA, USA) and appropriate buffers to yield an antisense ribonucleotide probe. Before use in nuclease protection assays, ribonucleotide probes were extracted with phenol:chloroform $(1: 1)$ and then chloroform. Unincorporated $\left[\alpha-{ }^{32} \mathrm{P}\right] \mathrm{rCTP}$ was removed by centrifugation through a G50 Sephadex spin column (Boehringer-Mannheim, Indianapolis, IN, USA). Ribonuclease protection assays (Lee \& Costlow 1987) were performed on $25 \mu \mathrm{g}$ total cellular RNA by using the RPA II kit (Ambion Inc., Austin, TX, USA). Protected mRNA fragments were identified by their electrophoretic mobility through $8 \%$ acrylamide, $8 \mathrm{M}$ urea gels (Acryl-A-Mix 8, Promega). Gels were dried and autoradiography was performed using XOMAT-AR film for $24 \mathrm{~h}$ at $-80{ }^{\circ} \mathrm{C}$ with intensifying screens.

\section{Statistical analyses}

Relative amounts of mRNA were measured by scanning densitometry of autoradiographs. The GP Tools version 3.0 (BioPhotonics Corporation, Ann Arbor, MI, USA) program was used to determine density. The $28 \mathrm{~S}$ ribosomal band from either a Northern blot (samples analyzed by Northern blotting) or an ethidium bromide-stained gel (samples analyzed by ribonuclease protection assay) was used to normalize the signal for each mRNA by calculating a ratio (arbitrary units) of mRNA to 28S RNA. Data were analyzed by least squares analysis of variance (SAS Institute 1987). A statistical model that included the main effect of tissue was used to determine differences in mRNA expression across different locations (i.e. liver versus ovary versus uterus etc.). Tissue means were separated by Duncan's multiple range test. A statistical model that included the main effect of treatment (rpST or control) was used to evaluate the response of a single tissue to treatment. The effect of replicate (1 to 3 ) was included for the analyses of IGF-I mRNA concentration. The statistical model included the effects of treatment, replicate, and treatment by replicate. Data are presented as least squares means \pm standard errors of the least squares mean. Unless stated otherwise, data were considered statistically significant at $P<0 \cdot 05$.

\section{Results}

\section{Fetal and placental development}

Maternal and fetal blood IGF-I and IGF-II, as well as gross weights and measurements of the uteri and fetuses, were reported in a previous publication (Sterle et al. 1995). The rpST-treated pigs had greater maternal blood IGF-I (268 \pm 14 versus $78 \pm 14 \mathrm{ng} / \mathrm{ml}$ on day 43 ; $\mathrm{rpST}$ versus control; $P<0.001)$, heavier fetuses $(18.1 \pm 0.6$ versus $16 \cdot 4 \pm 0.5 \mathrm{~g} ; \quad P<0 \cdot 05)$, heavier placentas $(71 \cdot 2 \pm 3 \cdot 5$ versus $58.4 \pm 3.4 \mathrm{~g} ; P<0.02)$, and tended to have greater fetal blood IGF-I $(14 \cdot 2 \pm 1 \cdot 4$ versus $10 \cdot 0 \pm 1 \cdot 5 \mathrm{ng} / \mathrm{ml}$; 


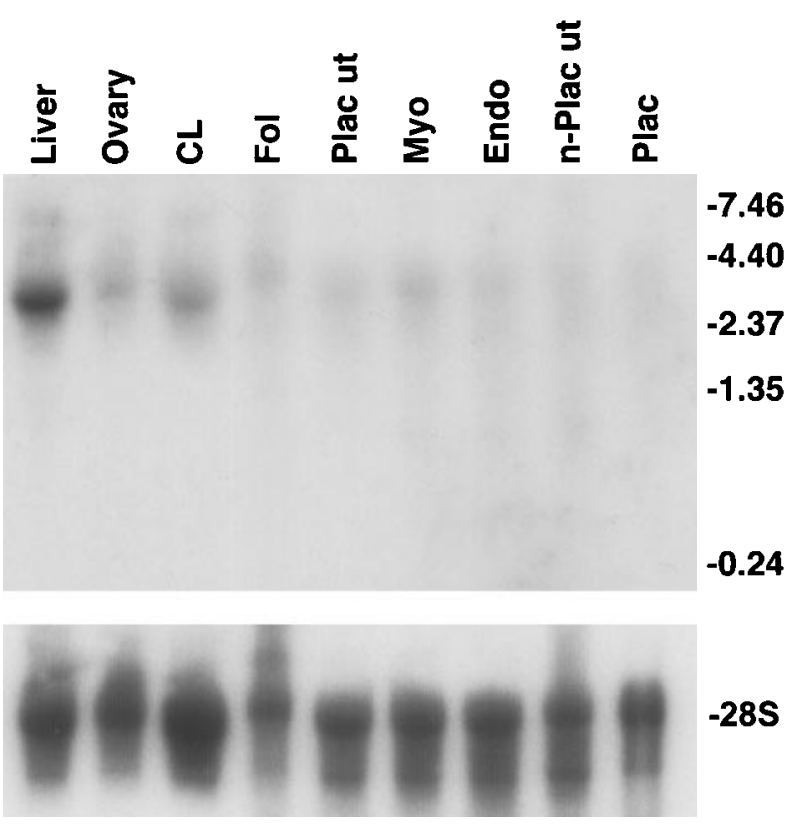

Figure 1 Autoradiograph of a Northern blot of somatotropin receptor mRNA and $28 \mathrm{~S}$ rRNA (control) in pregnant pig liver and reproductive tissues (ovary (mixture of corpus luteum, follicles and stroma), corpus luteum $(\mathrm{CL})$, ovarian follicles (Fol), placental uterus (Plac ut), myometrium (Myo), endometrium (Endo), non-placental uterus (n-Plac ut) and placenta (Plac)).

$P<0 \cdot 07)$ compared with controls. Number of fetuses per pregnancy, embryonic survival (day 44), uterine weight, and fetal blood IGF-II concentrations were similar for $\mathrm{rpST}$ and control animals. Maternal blood IGF-II concentrations decreased during $\mathrm{rpST}$ treatment (191 \pm 14 versus $283 \pm 14 \mathrm{ng} / \mathrm{ml}$ on day $43 ; \mathrm{rpST}$ versus control; $P<0 \cdot 05)$.

\section{Somatotropin receptor $m R N A$}

The somatotropin receptor mRNA was analyzed in two pigs (one rpST and one control; the effect of treatment on somatotropin receptor mRNA was not tested) to determine the relative concentrations of somatotropin receptor in liver and reproductive tissues. The somatotropin receptor mRNA was detected as $4.0 \mathrm{~kb}$ mRNA on Northern blots (Fig. 1; mRNA from one of two pigs is shown). There was an effect of tissue on somatotropin receptor mRNA concentration $(P<0 \cdot 01)$. Liver $(28 \cdot 5 \pm 3.6$ arbitrary units) expressed at least seven-fold more somatotropin receptor mRNA than reproductive tissues (CL $(3 \cdot 8 \pm 3 \cdot 6)$, follicles $(1 \cdot 2 \pm 3 \cdot 6)$, whole ovary (mixture of follicles, CL and stroma, $3 \cdot 0 \pm 3 \cdot 6$ ), non-placental uterus $(1 \cdot 7 \pm 3 \cdot 6)$, placental uterus $(1 \cdot 2 \pm 3 \cdot 6)$, endometrium (placental location, $1 \cdot 7 \pm 3 \cdot 6$ ), myometrium (placental location, $2 \cdot 4 \pm 3 \cdot 6)$ and placenta $(1 \cdot 1 \pm 3 \cdot 6))$. The con- centration of somatotropin receptor mRNA was similar within reproductive tissues $(P>0 \cdot 05)$.

\section{IGF-I $m R N A$}

A subset of samples was analyzed within a single ribonuclease protection assay for a tissue comparison of IGF-I mRNA concentration (Fig. 2; placenta was not analyzed because our preliminary Northern blot analyses failed to detect IGF-I mRNA in placenta). There was a tissue by treatment interaction $(P<0 \cdot 05)$ for IGF-I mRNA concentration (Fig. 2). Non-placental uterus (4.9 $\pm 0 \cdot 7$ arbitrary units) had a greater IGF-I mRNA concentration than placental uterus $(1 \cdot 7 \pm 0 \cdot 7)$ or ovary $(2 \cdot 1 \pm 0 \cdot 7)$, and the concentration of IGF-I mRNA in these tissues was not changed by rpST. The IGF-I mRNA concentration in liver, however, was increased in rpST-treated pigs $(6 \cdot 1 \pm 1 \cdot 0$ versus $0 \cdot 4 \pm 1 \cdot 0$; rpST versus control respectively). The analyses of additional samples confirmed that IGF-I mRNA concentration was increased in liver by rpST $(P<0 \cdot 01)$, whereas ovarian or uterine IGF-I mRNA concentrations were similar for rpST and control (Table 1). An effect of replicate was detected for uterus because the crowded uterus (replicate 3 ) had greater IGF-I mRNA concentrations in placental uterus $(0 \cdot 3 \pm 0 \cdot 1,0 \cdot 4 \pm 0 \cdot 1$ and $0 \cdot 8 \pm 0 \cdot 1$ for replicates 1,2 and 3 respectively; $P<0 \cdot 10)$ and non-placental uterus $(0 \cdot 1 \pm 0 \cdot 1,0 \cdot 2 \pm 0 \cdot 1$ and $0 \cdot 4 \pm 0 \cdot 1$; replicates 1,2 and 3 respectively; $P<0 \cdot 05)$. There was no effect of replicate on ovarian IGF-I mRNA concentration $(P>0 \cdot 05)$.

\section{IGF-II $m R N A$}

The mRNA for IGF-II was detected as a $2.5 \mathrm{~kb}$ band on Northern blots (Fig. 3A). For a tissue comparison, a subset of mRNA samples $(n=24)$ was analyzed for IGF-II mRNA on a single Northern blot (six tissues from two rpST and two control pigs). Greatest expression of mRNA for IGF-II was found in placenta (1.5 \pm 0.1 arbitrary units; Fig. 3A; tissue $P<0 \cdot 001)$. Lower concentrations of mRNA for IGF-II were found in liver $(0 \cdot 6 \pm 0 \cdot 1)$, CL $(0 \cdot 5 \pm 0 \cdot 1)$, follicle $(0 \cdot 7 \pm 0 \cdot 1)$, ovary $(0 \cdot 5 \pm 0 \cdot 1)$ and placental uterus $(0 \cdot 7 \pm 0 \cdot 1)$. The presence of IGF-II mRNA in placental uterus may have been associated with placental tissue interdigitated into the uterine wall, because PAG mRNA was detected within placental uterus samples (see below). These interdigitated placental fragments were not removed by manual stripping of the placenta from the uterus. Statistical analyses of the subset of mRNA samples did not detect a treatment or treatment by tissue interaction. Analyses of a greater number of samples for IGF-II mRNA resulted in similar conclusions (i.e. similar IGF-II mRNA concentrations for $\mathrm{rpST}$ and control groups within the liver, reproductive tissues and placenta (Fig. 3B; Table 1)). 

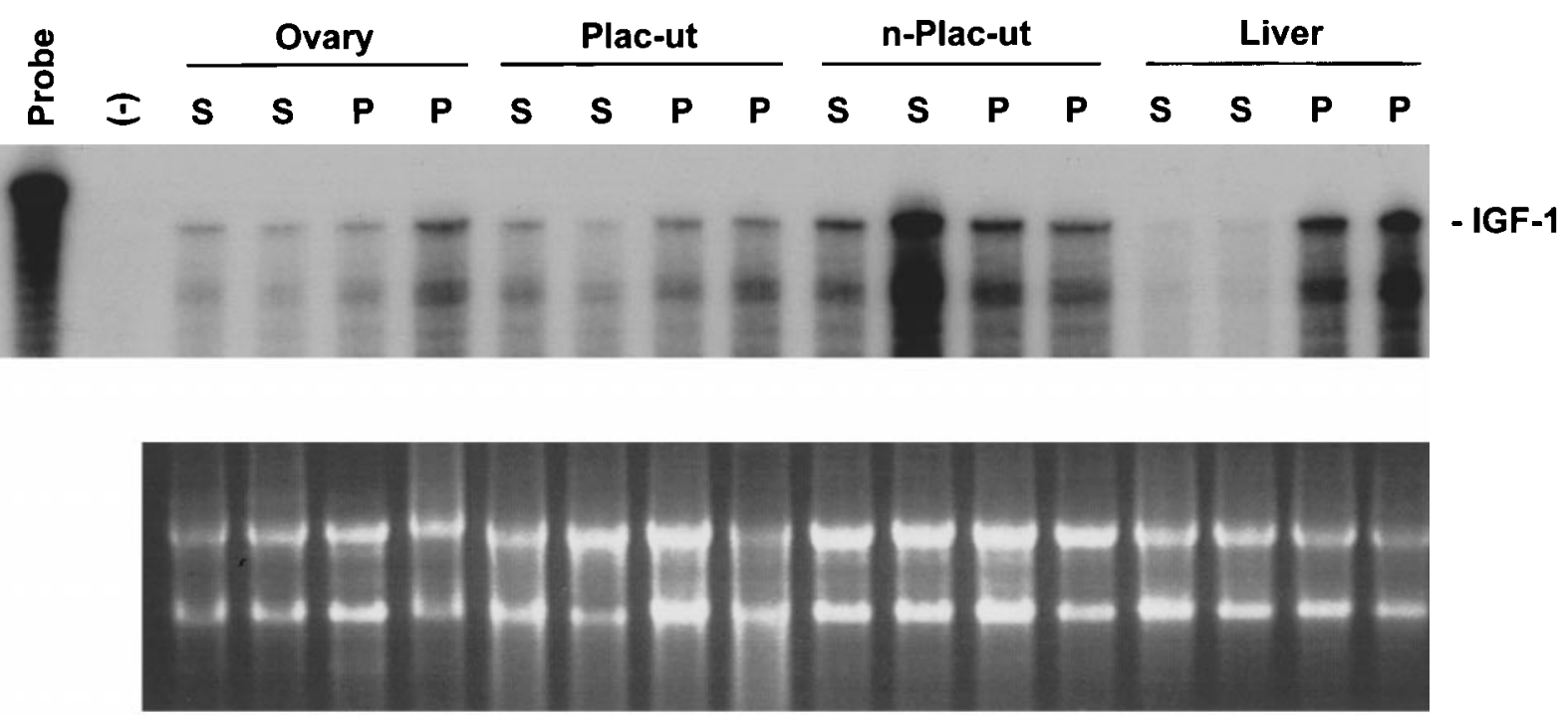

Figure 2 Autoradiograph of a ribonuclease protection assay for IGF-I mRNA in ovary, placental uterus (Plac-ut), non-placental uterus (n-Plac-ut) and liver in pregnant pigs (day 44) treated with rpST (P) or saline (S) from day 30 to day 43 of gestation. Ethidium bromidestained agarose gel of total cellular RNA used in the IGF-I ribonuclease protection assay is shown below the autoradiograph.

$(-)=$ negative control $($ tRNA).

\section{IGFBP-2 $m R N A$}

The mRNA for IGFBP-2 was detected as a $1.5 \mathrm{~kb}$ band on Northern blots. There was an effect of tissue $(P<0 \cdot 001)$ on IGFBP-2 mRNA concentration. The placental uterus and non-placental uterus had distinctly different IGFBP-2 mRNA concentrations. The expression of IGFBP-2 was greatest within the endometrial layer of the placental uterus $(26 \cdot 0 \pm 1 \cdot 1$ arbitrary units; Fig. 4A). The second greatest mRNA concentration was in placental uterus (sample included endometrium and myometrium; $15 \cdot 0 \pm 1 \cdot 1$ ). Other tissues (including non-placental uterus) contained less IGFBP-2 mRNA than placental endometrium or placental uterus (liver $(1 \cdot 1 \pm 1 \cdot 1)$, CL $(1 \cdot 9 \pm 1 \cdot 1)$, ovarian follicle $(2 \cdot 1 \pm 1 \cdot 1)$, whole ovary (mixture of follicles, CL and stroma; $1 \cdot 6 \pm 1 \cdot 1)$, myometrium $(1 \cdot 0 \pm 1 \cdot 1)$, non-placental uterus $(2 \cdot 5 \pm 1 \cdot 1)$ and placenta $(4 \cdot 6 \pm 1 \cdot 1))$. A greater number of samples was analyzed to determine the effects of treatment on IGFBP-2 mRNA concentration. The IGFBP-2 mRNA concentrations were similar within liver, ovary, uterus and placenta for rpST-treated and control pigs (Table 1; Fig. 4B).

\section{PAG $m R N A$}

The mRNA for PAG was detected as a $1.4 \mathrm{~kb}$ mRNA within the porcine placenta. When analyzed within

Table 1 Relative abundance of IGF-I, IGF-II, IGFBP-2 and PAG mRNA (least squares means) in tissues of gilts treated with rpST or saline $(\mathrm{SAL})$ during pregnancy. Data are presented for comparison within a tissue and between treatments. Data should not be used for between tissue comparisons because tissues were not necessarily balanced across each Northern blot or ribonuclease protection assay (treatments were balanced). See Results for comparisons between tissues

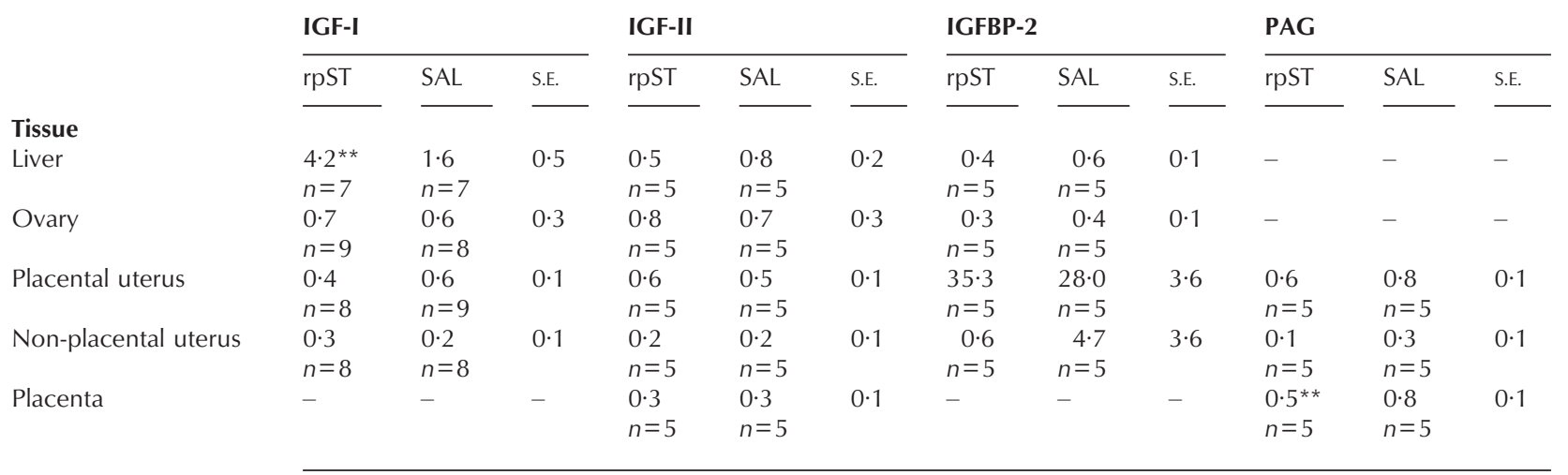

${ }^{* *} P<0 \cdot 01$ versus control. 

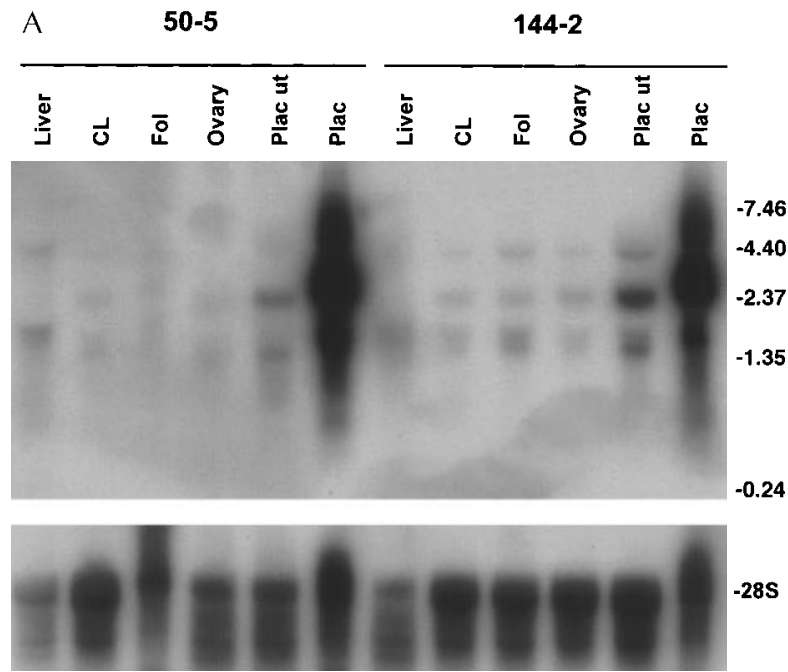

$-28 S$

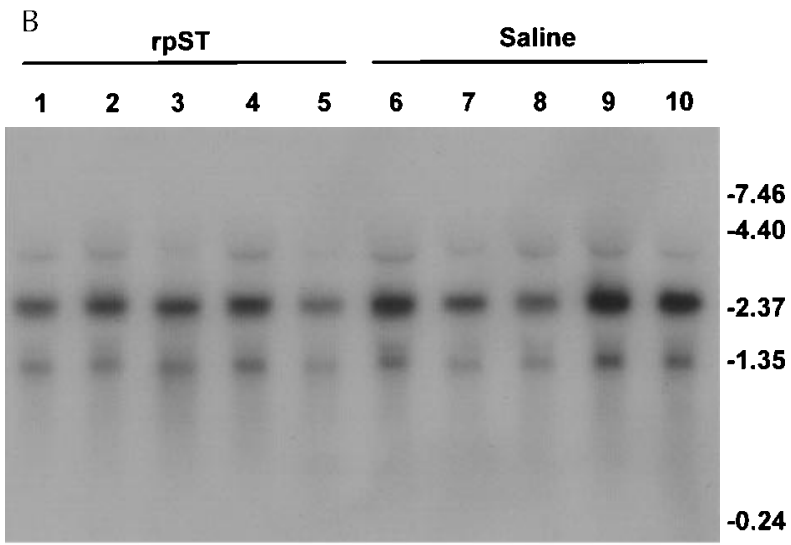

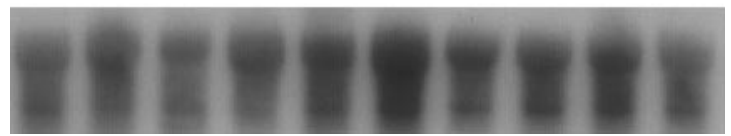

Figure 3 (A) Autoradiograph of a Northern blot of IGF-II mRNA and 28S rRNA (control) in pregnant pig liver and reproductive tissues (corpus luteum $(\mathrm{CL})$, ovarian follicles (Fol), ovary (mixture of $\mathrm{CL}$, follicles and stroma), placental uterus (Plac ut) and placenta (Plac)) from two pigs (50-5 and 144-2). (B) Autoradiograph of a Northern blot of IGF-II mRNA and 28S rRNA (control) in placental uterus in pregnant pigs (day 44) treated with rpST (1-5) or saline (6-10) from day 30 to day 43 of gestation.

reproductive tissue and liver, the PAG mRNA was also detected in placental uterus and endometrium (collected adjacent to the placenta; Fig. 5A). The presence of PAG mRNA in the placental uterus and endometrium suggested that residual placental tissue contaminates uterine tissue when the placenta is manually stripped from the uterus. The concentration of PAG mRNA was decreased in placenta (Table 1; Fig. 5B; $P<0 \cdot 01)$ for $\mathrm{rpST}$-treated compared with control pigs.

\section{Discussion}

Administration of $\mathrm{rpST}$ to pregnant pigs increased maternal blood IGF-I and the weight of fetuses and placentas (Sterle et al. 1995). Maternal liver responded to rpST with an increased IGF-I mRNA concentration (Fig. 2). The change in IGF-I gene expression agrees with the increase in blood IGF-I that occurs after rpST administration (Buonomo et al. 1995, Sterle et al. 1995). Similar changes in IGF-I gene expression were not observed
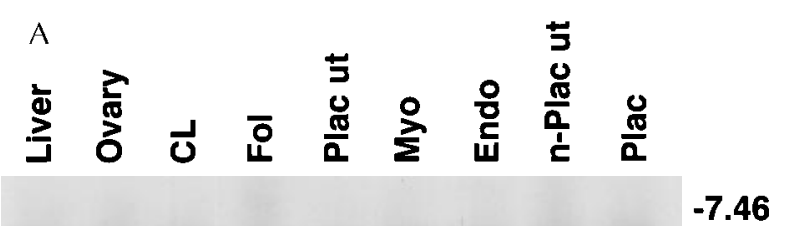

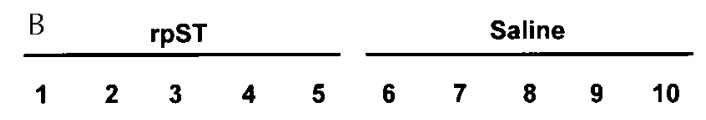

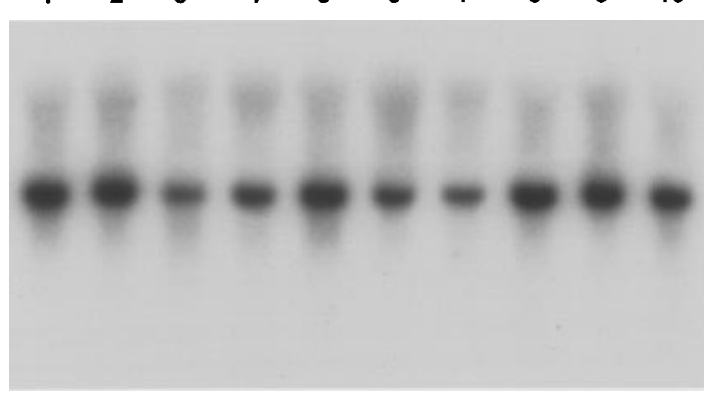

$-7.46$

$-4.40$

$-2.37$

$-1.35$

$-0.24$

$-0.24$

Figure 4 (A) Autoradiograph of a Northern blot of IGFBP-2 mRNA in pregnant pig liver and reproductive tissues (ovary (mixture of corpus luteum, follicles and stroma), corpus luteum (CL), ovarian follicles (Fol), placental uterus (Plac ut), myometrium (Myo), endometrium (Endo), non-placental uterus (n-Plac ut) and placenta (Plac)). See Fig. 1 for $28 S$ rRNA control (same Northern blot). (B) Autoradiograph of a Northern blot of IGFBP-2 mRNA in placental uterus in pregnant pigs (day 44) treated with rpST (1-5) or saline (6-10) from day 30 to day 43 of gestation. See Fig. 3B for $28 \mathrm{~S}$ rRNA control (same Northern blot). 


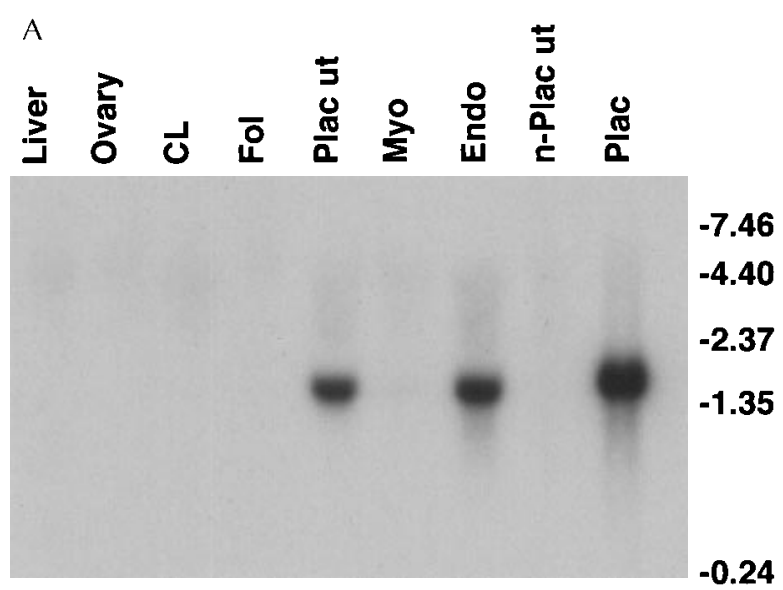

B rpst $\quad$ Saline

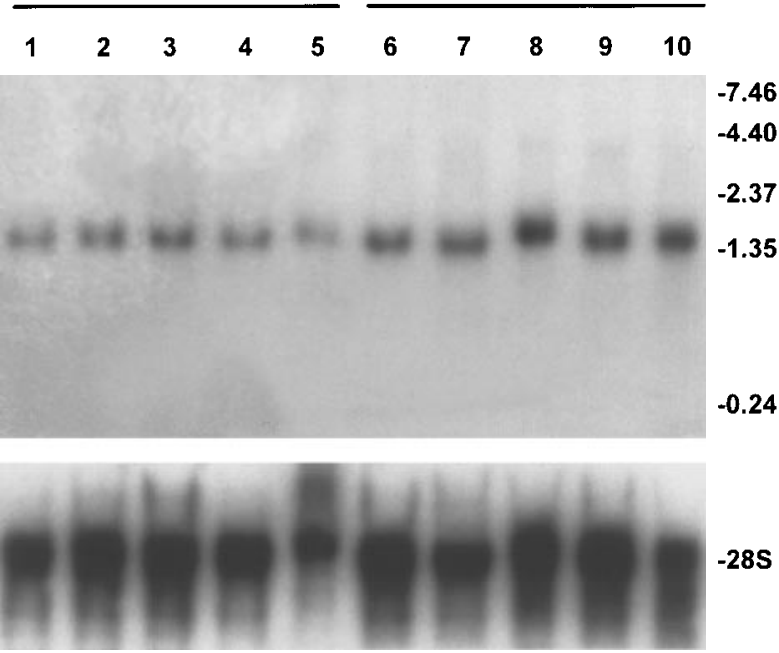

Figure 5 (A) Autoradiograph of a Northern blot of PAG mRNA in pregnant pig liver and reproductive tissues (ovary (mixture of corpus luteum, follicles and stroma), corpus luteum $(\mathrm{CL})$, ovarian follicles (Fol), placental uterus (Plac ut), myometrium (Myo), endometrium (Endo), non-placental uterus (n-Plac ut) and placenta (Plac)). See Fig. 1 for $28 S$ rRNA control (same Northern blot). (B) Autoradiograph of a Northern blot of PAG mRNA and $28 \mathrm{~S}$ rRNA (control) in placenta of pregnant pigs (day 44) treated with rpST (1-5) or saline (6-10) from day 30 to day 43 of gestation.

within reproductive tissues. The difference may reflect the relative concentrations of somatotropin receptor within liver compared with reproductive tissues (Fig. 1). The small concentration of somatotropin receptor in reproductive tissues may preclude a local response to $\mathrm{rpST}$. Our inability to detect differences in IGF-I mRNA concentration within reproductive tissues in response to somatotropin treatment agrees with data from laboratory and ruminant species, where somatotropin failed to increase uterine IGF-I (Mathews et al. 1989, Kirby et al. 1996). A uterine IGF-I response to somatotropin was found in the ovariectomized, hypophysectomized rat but the response was small compared with the IGF-I response to estradiol (Murphy \& Ghahary 1990). Skeletal muscle also had an undetectable IGF-I response to somatotropin (Coleman et al. 1994), perhaps because somatotropin receptors are not highly expressed in muscle (Florini et al. 1996). One study of pregnant pigs at similar stages of gestation showed increased IGF-I mRNA in the endometrium after rpST treatment (Kelley et al. 1995). Our study failed to confirm this previous observation, perhaps because we tested whole uterus, where the bulk of IGF-I mRNA arises from the myometrium (Song et al. 1996). Our conclusion is that somatotropin is not a dominant regulator of total uterine IGF-I mRNA concentration in pregnant pigs.

A third replicate was included for the IGF-I mRNA analyses. This was done because a definitive answer for the IGF-I response was not obtained after our analyses of replicates 1 and 2 . The third replicate included surgically induced uterine crowding. The uterine IGF-I mRNA concentration in pigs from replicate 3 was greater than those of pigs in replicates 1 and 2. This was only observed for uterine tissues (i.e. ovarian tissues were similar for IGF-I mRNA concentration across replicates). The induction of uterine IGF-I mRNA in response to a crowded uterus may stimulate uterine or placental growth and development. The present experiment was not designed with a contemporary control for uterine crowding within replicate 3 . The response of IGF-I mRNA concentration to a crowded uterus will, therefore, require additional studies.

The failure of a local (uterine) response to $\mathrm{rpST}$ demonstrates that enhanced fetal growth in rpST-treated pigs is not associated with increased IGF expression within the reproductive tract. Other mechanisms, therefore, must lead to increased fetal growth in rpST-treated gilts. One possibility is that increased IGF-I from the maternal liver acts as an endocrine growth factor for greater fetal growth and development. In previous studies, maternal IGF-I concentrations were correlated with the size of the fetus and birth weight (Hall et al. 1986, Gluckman \& Barry 1988, Lassarre et al. 1991, Gluckman et al. 1992). The greater maternal IGF-I in rpST-treated gilts may act through similar mechanisms. A second possibility is that rpST causes nutrient partitioning that favors fetal development. Injection of pigs with rpST increased plasma glucose and free fatty acid concentrations (Gopinath \& Etherton 1989, Dunshea et al. 1992, Buonomo et al. 1995, Hansen et al. 1997). The greater blood nutrient amounts may act as substrates for fetal and placental growth (Liu et al. 1994). Endocrine IGF-I and nutrient partitioning are only two of several mechanisms that may lead to enhanced 
fetal development. We did not examine changes in the expression of other fetal or placental growth factors in response to $\mathrm{rpST}$. Furthermore, somatotropin receptors are widely distributed within maternal and fetal tissues. Therefore, the effects of $\mathrm{rpST}$ may have been mediated directly at multiple sites.

An unexpected observation from this study was the unique distribution of IGF-I, IGF-II and IGFBP-2 mRNA within the pregnant uterus. The IGF-I and IGFBP-2 gene expression within the uterus adjacent to the placenta (placental uterus) was different from the IGF-I and IGFBP-2 gene expression within the uterus adjacent to the necrotic tip, where two neighboring placentas meet (non-placental uterus). The concentration of IGFBP-2 mRNA was increased several-fold in placental uterus compared with non-placental uterus (Fig. 4A). The presence of IGFBP-2 mRNA in placental uterus was not caused by contaminating placental tissue, because little IGFBP-2 mRNA was detected within placenta (Fig. 4A). Not all genes were up-regulated in placental uterus, however, because IGF-I mRNA concentration was lower in placental compared with non-placental locations (Fig. 2). The intense expression of IGFBP-2 in the region of the placental uterus suggests a specific induction of IGFBP-2 by molecules produced by the placenta. One hypothesis, which needs to be tested, is that the intense expression of IGF-II within the placenta (Fig. 3A) induces the expression of IGFBP-2 by the uterine endometrium. A similar relationship exists in the ovine uterus, in which placental cells expressing IGF-II are closely apposed by endometrial cells expressing IGFBP-2 (Delhanty \& Han 1993, Reynolds et al. 1997). The IGFBP-2 may act as a barrier to the movement of placental IGF-II from the pregnant uterus. In the non-placental uterus, IGFBP-2 may not be expressed because of inadequate placental signal from the necrotic tip.

A second unexpected finding was the relative expression of IGF-I in placental compared with non-placental uterus. We detected a decreased IGF-I mRNA concentration in the placental uterus compared with the nonplacental uterus. The difference in IGF-I mRNA between the two uterine locations probably reflects the local influence of the conceptus. In the pregnant porcine and ovine uterus, IGF-I mRNA decreases during pregnancy (Song et al. 1996, Reynolds et al. 1997). The placenta is an active site of IGF-II mRNA synthesis in both pig (Simmen et al. 1992) and sheep (Reynolds et al. 1997), and IGF-II synthesis by the placenta may inhibit the synthesis of IGF-I by the uterus through a local IGF negative feedback loop. Infusion of IGF-I into fetal sheep caused a decrease in IGF-I mRNA within fetal liver (Kind et al. 1996). It is possible, therefore, that the synthesis of IGF-I within a tissue is partially dependent on circulating concentrations of IGFs. Within the pregnant uterus, IGF-II synthesis by the placenta may feedback negatively on IGF-I synthesis by the uterus. The absence of IGF-II synthesis within the necrotic tip may lead to greater IGF-I mRNA synthesis in adjacent uterine locations.

PAG was measured because it is a major placental protein that could be used as a marker for chorionic tissue. Our initial concern was that the presence of IGF-II mRNA within placental uterus was caused by residual placental tissue that was not removed by manual stripping of the placenta from the uterus. Indeed, we detected PAG mRNA in our placental uterus samples and believe that some of the IGF-II mRNA in placental uterus arises from placental contamination. Manually stripping placenta from pregnant pig uterus (a routine technique in studies of pregnant pig endometrium; e.g. Simmen et al. 1992) does not necessarily remove placental tissues that are deeply interdigitated within the uterus. Studies of pregnant endometrium should be interpreted with caution, therefore, when placentas are manually stripped and the studied mRNA (e.g. IGF-II) is also expressed by placenta.

As expected, mRNA for PAG was abundant in placenta. An unexpected finding, however, was that rpST decreased PAG mRNA concentration. Although PAGs are intensely expressed within the placentas of sheep (Xie et al. 1996), cattle (Xie et al. 1994) and pigs (Szafranska et al. 1995), a specific function for PAG has not been identified. The reason for somatotropin-induced PAG down-regulation is also unknown. The response may be secondary to structural changes in the placenta or may reflect rpST- or IGF-I-dependent aspects of PAG physiology. Although the observation was impossible to measure, we experienced greater difficulty separating uterus from placenta in rpST-treated pigs. Samples for histological analyses were not collected in the present experiment. Subsequent histological studies of rpST-treated pregnant pigs, however, suggest greater attachment by more extensive interdigitation of the placenta and the maternal epithelium (J A Sterle, unpublished observations). The importance of decreased PAG mRNA concentration in the process is not known.

In conclusion, rpST did not cause a change in IGF-I, IGF-II or IGFBP-2 mRNA concentration within the pregnant uterus of the pig. Changes in IGF-I mRNA concentration were observed in maternal liver, where greatest somatotropin receptor mRNA concentration was detected. The pregnant pig uterus demonstrated regions of gene expression where placental and non-placental uterus have distinctly different IGF-I and IGFBP-2 mRNA concentrations. Increased fetal growth may result from a somatotropin- or IGF-I-mediated endocrine mechanism that may stimulate fetal growth or change nutrient availability to the fetus. Other mechanisms are also possible, including altered expression of other fetal or placental growth factors. The importance of each possibility to fetal growth will require further study. 


\section{Acknowledgements}

Contribution from the Missouri Agricultural Experiment Station, Journal Series Number 12734. The authors thank Dr R Michael Roberts (University of Missouri) for providing porcine PAG1 and PAG2 cDNA and Dr Robert L Matteri (USDA-ARS, Columbia, MO, USA) for porcine IGF-I and IGF-II cDNA.

\section{References}

Baker J, Liu JP, Robertson EJ \& Efstratiadis A 1993 Role of insulinlike growth factors in embryonic and postnatal growth. Cell $\mathbf{7 5}$ $73-82$.

Buonomo FC, Klindt J \& Yen JT 1995 Administration of porcine somatotropin by sustained release implant: growth factor and metabolic responses in crossbred white and genetically lean and obese boars and gilts. Journal of Animal Science 73 1318-1326.

Chomczynski P \& Sacchi N 1987 Single-step method of RNA isolation by acid guanidinium thiocyanate-phenol-chloroform extraction. Analytical Biochemistry 162 156-159.

Coleman ME, Russell L \& Etherton TD 1994 Porcine somatotropin $(\mathrm{pST})$ increases IGF-I mRNA abundance in liver and subcutaneous adipose tissue but not in skeletal muscle of growing pigs. Journal of Animal Science 72 918-924.

D'Ercole AJ \& Underwood LE 1981 Growth factors in fetal growth and development. In Fetal Endocrinology, pp 155-182. Eds MJ Novy \& JA Resko. New York: Academic Press.

Delhanty PJD \& Han VK 1993 The expression of insulin-like growth factor (IGF) binding protein-2 and IGF-II genes in the tissues of the developing ovine fetus. Endocrinology 132 41-52.

Dunshea FR, Harris DM, Bauman DE, Boyd RD \& Bell AW 1992 Effect of somatotropin on nonesterified fatty acid and glycerol metabolism in growing pigs. Journal of Animal Science 70 132-140.

Dziuk PJ 1968 Effect of number of embryos and uterine space on embryo survival in the pig. Journal of Animal Science 27 673-676.

Florini JR, Ewton DZ \& Coolican SA 1996 Growth hormone and the insulin-like growth factor system in myogenesis. Endocrine Reviews 17 481-517.

Gluckman PD \& Barry TN 1988 Relationships between plasma concentrations of placental lactogen, insulin-like growth factors, metabolites and lamb size in late gestation ewes subject to nutritional supplementation and in their lambs at birth. Domestic Animal Endocrinology 5 209-217.

Gluckman PD, Morel PCH, Ambler GR, Breier GH, Blair HT \& McCutcheon SN 1992 Elevating maternal insulin-like growth factor-I in mice and rats alters the pattern of fetal growth by removing maternal constraint. Journal of Endocrinology 134 R1-R3.

Gopinath R \& Etherton TD 1989 Effects of porcine growth hormone on glucose metabolism of pigs. I. Acute and chronic effects on plasma glucose and insulin status. Journal of Animal Science $\mathbf{6 7}$ 682-688.

Hall K, Hansson U, Lundin G, Luthman M, Persson B, Povoa G, Stangenberg M \& Ofverholm U 1986 Serum levels of somatomedins and somatomedin binding-protein in pregnant women with type I or gestational diabetes and their infants. Journal of Clinical Endocrinology and Metabolism 63 1300-1306.

Han VK \& Hill DJ 1992 Growth factors in embryonic and fetal development. In Insulin-like Growth Factors: Structure and Biological Functions, pp 178-208. Ed PN Schofield. Oxford: Oxford University Press.

Hansen JA, Yen JT, Klindt J, Nelssen JL \& Goodband RD 1997 Effects of somatotropin and salbutamol in three genotypes of finishing barrows: blood hormones and metabolites and muscle characteristics. Journal of Animal Science 75 1810-1821.
Hauser SD, McGrath MF, Collier RJ \& Krivi GG 1990 Cloning and in vivo expression of bovine growth hormone receptor mRNA. Molecular and Cellular Endocrinology 72 187-200.

Jones JI \& Clemmons DR 1995 Insulin-like growth factors and their binding proteins: biological actions. Endocrine Reviews 16 3-34.

Kelley RL, Jungst SB, Spencer TE, Owsley WF, Rahe CH \& Mulvaney DR 1995 Maternal treatment with somatotropin alters embryonic development and early postnatal growth of pigs. Domestic Animal Endocrinology 12 83-94.

Kind KL, Owens JA, Lok F, Robinson JS, Quinn KJ, Mundy L, Gilmour RS \& Owens PC 1996 Intravenous infusion of insulin-like growth factor I in fetal sheep reduces hepatic IGF-I and IGF-II mRNAs. American Journal of Physiology 271 R1632-R1637.

Kirby CJ, Thatcher WW, Collier RJ, Simmen FA \& Lucy MC 1996 Effects of growth hormone and pregnancy on expression of growth hormone receptor, insulin-like growth factor-I, and insulin-like growth factor binding protein-2 and -3 genes in bovine uterus, ovary, and oviduct. Biology of Reproduction 55 996-1002.

Lassarre C, Hardouin S, Daffos F, Forestier F, Frankenne F \& Binoux M 1991 Serum insulin-like growth factors and insulin-like growth factor binding proteins in the human fetus. Relationships with growth in normal subjects and in subjects with intrauterine growth retardation. Pediatric Research 29 219-225.

Lee JJ \& Costlow NA 1987 A molecular titration assay to measure transcript prevalence levels. Methods in Enzymology 152 633-648.

Liu L, Harding JE, Evans PC \& Gluckman PD 1994 Maternal insulin-like growth factor-I infusion alters feto-placental carbohydrate and protein metabolism in pregnant sheep. Endocrinology 135 895-900.

Lucy MC, Collier RJ, Kitchell ML, Dibner JJ, Hauser SD \& Krivi GG 1993 Immunohistochemical and nucleic acid analysis of growth hormone receptor populations in the bovine ovary. Biology of Reproduction 48 1219-1227.

Mathews LS, Norstedt G \& Palmiter RD 1989 Regulation of insulin-like growth factor I gene expression by growth hormone. Proceedings of the National Academy of Sciences of the USA 83 9343-9347.

Murphy LJ \& Ghahary A 1990 Uterine insulin-like growth factor-1: regulation of expression and its role in estrogen-induced uterine proliferation. Endocrine Reviews 11 443-453.

Owens JA 1991 Endocrine and substrate control of fetal growth: placental and maternal influences and insulin-like growth factors. Reproduction, Fertility and Development 3 501-517.

Rechler MM 1997 Growth inhibition by insulin-like growth factor (IGF) binding protein-3 - what's IGF got to do with it? Endocrinology 138 2645-2647.

Rehfeldt C, Fiedler I, Weikard R, Kanitz E \& Ender K 1993 It is possible to increase skeletal muscle fibre number in utero. Bioscience Reports 13 213-220.

Reynolds TS, Stevenson KR \& Wathes DC 1997 Pregnancy-specific alterations in the expression of the insulin-like growth factor system during early placental development in the ewe. Endocrinology 138 886-897.

SAS Institute 1987 SAS User's Guide: Statistics, version 6. Cary, NC: SAS Institute, Inc.

Simmen FA, Simmen RCM, Geisert RD, Marina-Botte F, Bazer FW \& Terqui M 1992 Differential expression, during the estrous cycle and pre- and postimplantation conceptus development, of messenger ribonucleic acids encoding components of the pig uterine insulin-like growth factor system. Endocrinology 130 1547-1556.

Simmen RCM, Simmen FA, Hofig A, Farmer SJ \& Bazer FW 1990 Hormonal regulation of insulin-like growth factor gene expression in pig uterus. Endocrinology 127 2166-2174.

Song S, Lee CY, Green ML, Chung CS, Simmen RCM \& Simmen FA 1996 The unique endometrial expression and genomic organization of the porcine IGFBP-2 gene. Molecular and Cellular Endocrinology 120 193-202. 
Sterle JA, Cantley TC, Lamberson WR, Lucy MC, Gerrard DE, Matteri RL \& Day BN 1995 Effects of recombinant porcine somatotropin on placental size, fetal growth, and IGF-I and IGF-II concentrations in pigs. Journal of Animal Science 73 2980-2985.

Szafranska B, Xie S, Green J \& Roberts RM 1995 Porcine pregnancy-associated glycoproteins: new members of the aspartic proteinase gene family expressed in trophectoderm. Biology of Reproduction 53 21-28.

Xie S, Low BG, Nagel RJ, Beckers JF \& Roberts RM 1994 A novel glycoprotein of the aspartic proteinase gene family expressed in bovine placental trophectoderm. Biology of Reproduction $\mathbf{5 1}$ $1145-1153$.

Xie S, Nagel RJ, Green J, Beckers JF \& Roberts RM 1996 Trophoblast-specific processing and phosphorylation of pregnancy-associated glycoprotein-1 in day 15 to 25 sheep placenta. Biology of Reproduction 54 122-129.

Yuan W, Lucy MC \& Smith MF 1996a Messenger ribonucleic acid for insulin-like growth factors-I and -II, insulin-like growth factor binding protein-2, gonadotropin receptors, and steroidogenic enzymes in porcine follicles. Biology of Reproduction 55 1045-1054.

Yuan W, Sterle JA, Cantley TC, Lamberson WR, Day BN \& Lucy MC $1996 b$ Responses of porcine corpora lutea to somatotropin administration during pregnancy. Journal of Animal Science $\mathbf{7 4}$ 873-878.

Received 5 March 1998

Accepted 13 July 1998 